\title{
EDUCATION AND TRAINING Clinical leadership fellow schemes for junior doctors: a brief overview of available schemes and how to apply
}

\author{
Authors: Helen Grote, ${ }^{A}$ Joanna Smith, ${ }^{B}$ Jayne Little ${ }^{C}$ and Michelle Horridge ${ }^{D}$
}

\begin{abstract}
Medical training in the UK provides limited exposure to formal training in leadership and management, and yet the role of a consultant or general practitioner requires such skills which deal with commissioning arrangements, service transformation, quality improvement, Care Quality Commission visits, complaints and supervision of junior colleagues. A number of clinical fellowships in leadership now exist to bridge this gap, and provide training in leadership and management, together with experiential learning in a complex organisation. Well-established leadership schemes suited to junior doctors include the National Medical Director's Clinical Fellow Scheme, the Royal College of Physicians' chief registrar scheme, the Darzi Fellowship scheme and local schemes run by Health Education England. Here we describe and compare our experience of these schemes, and outline what junior doctors should consider when applying for a clinical fellowship.
\end{abstract}

KEYWORDS: Junior doctors, clinical fellowships and leadership schemes

\section{Introduction}

Medical training in the UK, from foundation year 1 through to certificate of completion of training, provides the means to acquire the knowledge and skills in a chosen specialty through experiential learning, practical procedures and plenty of exams along the way. The role of a consultant or general practitioner (GP) goes beyond clinical acumen requiring teamwork, together with leadership and management skills to deal with commissioning arrangements, service transformation, quality improvement, Care Quality Commission (CQC) visits, complaints and supervision of junior colleagues.

Authors: ${ }^{A}$ neurology registrar, Imperial College Healthcare NHS Trust, London, UK and clinical fellow, Care Quality Commission, London, UK; ${ }^{B}$ geriatrics registrar, Croydon Health Services NHS Trust, Croydon, UK; ${ }^{C}$ rheumatology registrar, Manchester University NHS Foundation Trust, Manchester, UK; ${ }^{D}$ paediatric surgery registrar, Rotherham NHS Foundation Trust, Rotherham, UK
While the requirements of the portfolio box marked 'leadership and management' can (for most specialty postgraduate curricula), be completed through a 2-day course, it has been the experience of the authors that these are rather theory-based, with too much focus on topics such as 'The structure of the NHS' and not enough emphasis on the practical application of skills or reflective learning required to be an effective leader.

Leadership and management skills are best developed through experiential learning, supported by a programme of formal teaching, reflective practice, and access to senior leaders and role models. A variety of fellowship schemes now exist which are particularly suitable for trainees to develop their leadership skills, through a full- or part-time programme, based in a clinical setting or an external organisation.

We are specialty registrars currently undertaking different fellowship schemes. Here, we compare what our respective schemes offer, describe our experiences and outline what to consider if you're a trainee looking to apply for a clinical fellowship with a view to improving your leadership skills.

\section{The National Medical Director's Clinical Fellow Scheme}

\section{Dr Helen Grote, ST7 neurology registrar}

The unique opportunity to develop leadership skills while working in national organisation made the National Medical Director's Clinical Fellow Scheme hugely appealing. The CQC was my first choice post; I felt that the opportunity to visit hospitals, learn from examples of good practice and understand how regulation is used to promote both quality assurance and improvement would be extremely valuable for my future career as a consultant physician.

My key projects have included a national programme to examine how mental health care is provided in acute hospitals and establishing a programme of junior doctor focus groups to inform the well-led domain of CQC's inspections.

I've been surprised by how much responsibility I have been given, and the need to engage with other stakeholders around my work has challenged me to work on silencing my 'imposter syndrome', develop my networking skills and ask senior people for help. I still take on more than I should, though; the work laptop has come home with me most evenings and weekends, and I need to get better at saying 'no'. The absence of patient contact was difficult at first; I've always derived huge satisfaction from helping 
individuals understand and manage their symptoms, and the year has confirmed my desire to pursue clinical practice alongside opportunities to lead.

\section{The Darzi Fellowship scheme}

\section{Dr Joanna Smith, ST4 geriatrics registrar}

The Darzi Fellowship is a postgraduate certificate programme combining leadership development and organisational change open to clinicians from all backgrounds.

I was enthused by a Darzi project in community geriatrics, leading the development of an integrated team to work towards novel approaches in caring for the most 'complex' of Croydon's elderly population. As the year progressed, many further avenues of interest evolved such as co-designing and delivering a 'Thinking systems' workshop series spanning organisational and professional boundaries. The experience of systems leadership has given me a found awareness of the central role of relationships, context and purpose in delivering complex change, ${ }^{1}$ with learning focused on the value of, and need for, more collective models of leadership. $^{2}$

My personal reflections on the fellowship so far are that it has been able to constructively challenge my previously held assumptions and beliefs, and has transformed my perceptions of learning and leading. I have acquired tools to understand and develop the systems I am living and working in for the better, while giving me both the confidence to challenge the status quo and the hope that change is possible. It has been a demanding and humbling experience, but one which has given me countless opportunities, a fundamental awareness of perspective and has inspired me to strive towards 'doing better things'. ${ }^{2}$

\section{The RCP's chief registrar scheme}

The RCP's chief registrar scheme is a 12-month workplace-based leadership programme, supported by a tailored education and training package, open to all senior trainees of any specialty. It equips senior trainees with the requisite technical and leadership skills to directly improve quality and safety systematically, sustainably and effectively.

\section{Dr Jayne Little, ST6 rheumatology}

For me the great attraction of this scheme was the promise of protected time. As a clinician, I frequently encountered structural problems that I would recognise, endure and then leave unaltered for my successors. The most pleasant surprise of my year as chief registrar was how many of these problems proved soluble given the time to think, engage the right people and apply a rigorous quality improvement (QI) methodology.

The formal QI training was highly engaging because I was able to apply the content directly to day-to-day problem solving. Over the past year, I have led on trust-wide projects including the development of fellowship posts to reduce rota gaps, and a network of QI champions. The opportunity to experience varied leadership personalities and practices through direct participation in the hospital management structure has certainly helped me to develop my own leadership style.

There have been challenges, however. Leading change in specialties other than my own and earning the respect of senior colleagues has required persistence and tact. I've also been surprised by the cultural differences between different generations of doctors. Changes in the shape of training and structure of rotations have led to a rapid change in attitudes. As a result, I found representing the concerns of the junior workforce more challenging than I had expected.

I have thoroughly enjoyed my time on the scheme. The guidance provided by my mentor, the RCP and the other chief registrars has been invaluable.

\section{The Health Education England Future Leaders Programme}

\section{Dr Michelle Horridge, staff grade registrar, paediatric} surgery

Health Education England (HEE) offers a variety of local leadership schemes; including the Future Leaders Programme offered by HEE Yorkshire and Humber. This offers doctors and allied healthcare professionals the opportunity to undertake a 1-year programme incorporating a postgraduate certificate in clinical leadership, alongside leading projects in a local organisation.

I am currently working on three projects and am particularly excited by the work I am doing to improve the emotional support provided to staff following traumatic events at work. This speaks to my core values, which I have been able to identify through the courses available to the 'future leaders'. I have had the autonomy to create and develop this project, with senior leadership support, giving me further insight into organisational culture, project management and development of skills and networks.

It has been liberating and, at the same time, daunting to be working on large-scale projects. I have felt trusted and given responsibility with regards to people, budgets and involvement with the executive board. The fellowship has highlighted personal strengths which I have had the opportunity to develop further. The experience of being embedded within a team for a whole year and not rotating has also provided a real opportunity to forge good working relationships with a diverse and knowledgeable group of colleagues. This year has led to me feeling inspired, motivated and excited about my work.

\section{The value of clinical fellowships}

While the National Medical Director's Clinical Fellow Scheme provides the opportunity to work on national projects, local schemes such as the Darzi, RCP and HEE schemes are equally valuable in providing opportunities in experiential leadership, and access to senior NHS leaders. Furthermore, learning to make a difference locally is a useful skill which provides the satisfaction of facilitating tangible benefits in patient care, which are often easier to appreciate in a short timeframe and can, in some cases, be scaled up and replicated elsewhere.

No new venture is without challenges, but we have all found these integral to the process of 'learning to lead' - and, on occasion, these challenges (and sometimes failures) produced the most valuable learning lessons. We all became quite absorbed in our respective projects, and learning to say 'no' was difficult at times. Approaching the end of our fellowships, our next challenge is to navigate how best to continue developing our new approaches to leadership and systems as we re-enter the clinical workforce, as well as adjusting to the reduced autonomy that comes with being a junior doctor once again.

We have all enjoyed the opportunity to test out leadership skills in new roles, as well as the opportunities to network, socialise and 
Table 1. An overview of available fellowship schemes for junior doctors interested in clinical leadership

\begin{tabular}{|c|c|c|c|c|c|c|}
\hline Scheme & Organiser & Open to & Duration & Host organisation & $\begin{array}{l}\text { Leadership and } \\
\text { management training }\end{array}$ & Salary \\
\hline $\begin{array}{l}\text { National } \\
\text { Medical } \\
\text { Director's } \\
\text { Clinical } \\
\text { Fellow } \\
\text { Scheme }\end{array}$ & FMLM & $\begin{array}{l}\text { Doctors post-FY2 } \\
\text { to penultimate } \\
\text { year of training. } \\
\text { GP trainees can } \\
\text { apply in final year } \\
\text { of training. Junior } \\
\text { doctors without an } \\
\text { NTN can apply. }\end{array}$ & $\begin{array}{l}12 \text { months } \\
\text { full time. If an } \\
\text { NTN holder, the } \\
\text { post is OOPE } \\
\text { and does not } \\
\text { count towards } \\
\text { training. }\end{array}$ & $\begin{array}{l}\text { Mostly national ALBs } \\
\text { in London (HEE/NHSE/ } \\
\text { NHSI/CQC/GMCI } \\
\text { Health Foundation). } \\
\text { Some posts in } \\
\text { Manchester. }\end{array}$ & $\begin{array}{l}\text { Intensive 6-day } \\
\text { induction programme. } \\
\text { Development events } \\
\text { throughout the year } \\
\text { organised by FMLM and } \\
\text { NHSE. } \\
\text { Action learning sets. } \\
\text { Celebration event at end } \\
\text { of year. }\end{array}$ & $\begin{array}{l}\text { Matched to current } \\
\text { NHS grade (and } \\
\text { banding). }\end{array}$ \\
\hline $\begin{array}{l}\text { RCP's chief } \\
\text { registrar } \\
\text { scheme }\end{array}$ & RCP & $\begin{array}{l}\text { Doctors (including } \\
\text { non-physicians) in } \\
\text { training from at } \\
\text { least ST4. } \\
\text { Must have an } \\
\text { NTN. }\end{array}$ & $\begin{array}{l}\text { Minimum } \\
40-50 \% \text { time } \\
\text { protected for } \\
\text { chief registrar } \\
\text { activity for } \\
\text { minimum } \\
12 \text { months. } \\
\text { Can be OOPE/ } \\
\text { part of training. }\end{array}$ & $\begin{array}{l}\text { Based at hospital trusts } \\
\text { across the country. }\end{array}$ & $\begin{array}{l}\text { Development } \\
\text { programme (five } \times 2 \\
\text { days) organised by RCP. } \\
\text { Action learning sets. }\end{array}$ & $\begin{array}{l}\text { Matched to current } \\
\text { NHS grade (and } \\
\text { banding) }\end{array}$ \\
\hline $\begin{array}{l}\text { Darzi } \\
\text { Fellowship } \\
\text { scheme }\end{array}$ & $\begin{array}{l}\text { London } \\
\text { South Bank } \\
\text { University } \\
\text { via host } \\
\text { organisations }\end{array}$ & $\begin{array}{l}\text { Early career } \\
\text { leaders (ST4+ or } \\
\text { band 6-8). } \\
\text { Open to doctors, } \\
\text { nurses and } \\
\text { allied healthcare } \\
\text { professionals. }\end{array}$ & $\begin{array}{l}12 \text { months } \\
\text { full time. If in } \\
\text { training, post is } \\
\text { an OOPE and } \\
\text { does not count } \\
\text { towards training. }\end{array}$ & $\begin{array}{l}\text { Host is the sponsoring } \\
\text { organisation of the } \\
\text { project. This may be } \\
\text { a CCG, local council, } \\
\text { academic health } \\
\text { science network or } \\
\text { hospital trust. Separate } \\
\text { cohorts are based in } \\
\text { London and KSS. }\end{array}$ & $\begin{array}{l}\text { University programme } \\
\text { for postgraduate } \\
\text { certificate leadership in } \\
\text { health (Darzi). } \\
\text { Online global course } \\
\text { (MIT). } \\
\text { Coaching. } \\
\text { Action learning sets. }\end{array}$ & $\begin{array}{l}\text { Matched to current } \\
\text { NHS grade (and } \\
\text { banding). } \\
\text { AfC grade for } \\
\text { allied healthcare } \\
\text { professionals. }\end{array}$ \\
\hline $\begin{array}{l}\text { HEE } \\
\text { fellowships } \\
\text { (including } \\
\text { HEE QI } \\
\text { fellowships) }\end{array}$ & $\begin{array}{l}\text { Via local } \\
\text { deanery }\end{array}$ & $\begin{array}{l}\text { See local } \\
\text { advertisement on } \\
\text { HEE website. } \\
\text { Trainee doctors, } \\
\text { dentists and public } \\
\text { health registrars } \\
\text { GPST2/ST3+ (must } \\
\text { hold an NTN). } \\
\text { Allied healthcare } \\
\text { professionals. } \\
\text { SAS doctors. }\end{array}$ & $\begin{array}{l}12 \text { months } \\
\text { full time. If in } \\
\text { training, post is } \\
\text { an OOPE and } \\
\text { does not count } \\
\text { towards training. }\end{array}$ & $\begin{array}{l}\text { Based within region } \\
\text { applied to. }\end{array}$ & $\begin{array}{l}\text { Postgraduate certificate } \\
\text { in leadership, or other } \\
\text { relevant subject eg } \\
\text { medical education / } \\
\text { health and social care. } \\
\text { Coaching. } \\
\text { Action learning sets. } \\
\text { Future leaders } \\
\text { conference. }\end{array}$ & $\begin{array}{l}\text { Matched to current } \\
\text { NHS grade (and } \\
\text { banding). } \\
\text { AfC grade for } \\
\text { allied healthcare } \\
\text { professionals. }\end{array}$ \\
\hline $\begin{array}{l}\text { NHS } \\
\text { Leadership } \\
\text { Academy } \\
\text { schemes }\end{array}$ & $\begin{array}{l}\text { NHS } \\
\text { Leadership } \\
\text { Academy }\end{array}$ & $\begin{array}{l}\text { Eligibility criteria } \\
\text { for programmes } \\
\text { vary; ranging } \\
\text { from the Edward } \\
\text { Jenner programme } \\
\text { for students and } \\
\text { newly qualified } \\
\text { staff, through } \\
\text { to development } \\
\text { courses for aspiring } \\
\text { chief executives. }\end{array}$ & $\begin{array}{l}\text { Courses vary in } \\
\text { duration from } \\
6 \text { weeks to } 24 \\
\text { months. }\end{array}$ & $\begin{array}{l}\text { Most courses are } \\
\text { undertaken through } \\
\text { self-directed study and } \\
\text { work-based application } \\
\text { at the employee's } \\
\text { usual place of work. } \\
\text { More advanced courses } \\
\text { offered by the NHS } \\
\text { Leadership Academy } \\
\text { may involve residentials } \\
\text { in Leeds or London. }\end{array}$ & $\begin{array}{l}\text { The training provided } \\
\text { varies depending } \\
\text { on the level of the } \\
\text { course. All lead to a } \\
\text { certificate from the NHS } \\
\text { Leadership Academy. } \\
\text { Those undertaking } \\
\text { the Elizabeth Garrett } \\
\text { Anderson programme } \\
\text { work towards an MSc in } \\
\text { healthcare leadership. }\end{array}$ & $\begin{array}{l}\text { Current NHS grade. } \\
\text { Bursaries are available } \\
\text { to support talented } \\
\text { individuals from } \\
\text { under-represented } \\
\text { groups who would } \\
\text { otherwise be unable } \\
\text { to afford the NHS } \\
\text { Leadership Academy } \\
\text { programmes. }\end{array}$ \\
\hline
\end{tabular}

${ }^{a}=$ parallel schemes, run by the FMLM are also run for early career pharmacists (Chief Pharmaceutical Officer's Clinical Fellow Scheme) and dentists (Chief Dental Officer's Clinical Fellow Scheme), these are also 12-month, full-time posts, based in national organisations - details can be found on the FMLM website; AfC = Agenda for Change; $\mathrm{ALBs}=$ arm's length bodies; $C \mathrm{CG}=$ clinical commissioning group; $\mathrm{CQC}=$ Care Quality Commission; FMLM = Faculty of Medical Leadership and Management; FY2 = foundation year 2; GMC = General Medical Council; GP = general practitioner; HEE = Health Education England; KSS = Kent, Surrey and Sussex; MIT = Massachusetts Institute of Technology; NHSE = NHS England; NHSI = NHS Improvement; NTN = national training number; OOPE = out of programme experience; QI = quality improvement; RCP = Royal College of Physicians; SAS = specialty and associate specialist; ST = specialty trainee. 
Table 2. Links to apply for fellowship schemes

Scheme
National Medical
Director's Clinical
Fellow Scheme
RCP's chief
registrar scheme

Darzi Fellowship scheme

HEE local fellowship schemes

NHS Leadership Academy schemes

\section{Application window}

Applications open in December each year.

Organisations need to declare an interest to host a chief registrar by November each year.

Local recruitment (adverts via NHS Jobs) usually occurs from October to March each year.

Organisations need to declare an interest to host a Darzi fellow by February for London and by October for KSS.

Recruitment for fellows occurs from April each year in London, and from November each year in KSS.

See local HEE website for details.

Application window varies depending on the scheme.

See website for details.

\section{Application link}

www.fmlm.ac.uk/programme-services/individual-support/ national-medical-directors-clinical-fellow-scheme

Chief registrar posts are usually advertised via NHS Jobs and on the HEE PGMDE Synapse portal.

Administered via London South Bank University, for: London - www.londonleadershipacademy.nhs.uk KSS - www.kssahsn.net/darzi-fellowship/Pages/default.aspx Posts are advertised by host trusts and on NHS jobs.

See local HEE site: the content, eligibility criteria and recruitment process for schemes vary by region. www.leadershipacademy.nhs.uk/programmes

HEE = Health Education England; KSS = Kent, Surrey and Sussex; PGMDE = postgraduate medical and dental education; RCP = Royal College of Physicians.

share ideas with other fellows. The opportunity for 'headspace' to reflect individually, as well as through action learning sets, has facilitated important personal development, giving us all a greater understanding of our own traits and strengths as leaders, and an understanding of the diversity in others. Alongside formal training, we have all appreciated the flexibility inherent in the schemes, enabling valuable opportunities to attend events, conferences and pursue other professional interests. The added autonomy also provided space for learning journeys and productive conversations with leaders in other organisations.

The value of clinical fellowships goes beyond personal and professional growth for the individual, however. Leadership at every level is influential in determining organisational performance, ${ }^{3}$ and the need for doctors to step up is clear; ${ }^{4}$ increased medical engagement and good leadership correlate with improved patient care and outcomes. ${ }^{5,6}$ However, healthcare is a complex environment, characterised by 'wicked problems "7 for which there is no clear solution, and where a collective, collaborative model of leadership brings the greatest benefit to organisations, rather than 'heroic' leadership by individuals. ${ }^{3,8,9}$

There is increasing evidence that that the acquisition of leadership qualifications and portfolio competencies alone are no substitute for programmes which foster real-world experience of knowledge, enquiry, adaptability and collaboration to develop effective leadership. ${ }^{8}$ All of the leadership schemes described here fulfil the characteristics of effective leadership development programmes which combine personal development, and opportunities to link theory to practice in a complex organisation. ${ }^{10}$ Independent evaluations of the RCP's chief registrar scheme, ${ }^{11}$ the National Medical Director's Clinical Fellow Scheme ${ }^{12}$ and the Darzi scheme ${ }^{13}$ have also confirmed that fellows provide a valuable benefit to host organisations though improvements in quality and safety, cost savings and deliverables including publications, reports and research studies.

\section{Applying for fellowships}

A summary of these clinical fellow schemes is provided in Table 1, with details of how to apply in Table 2. In addition, the NHS Leadership Academy provides a variety of leadership schemes which incorporate online and face-to-face training, supplemented by work-based application, leading to an NHS Leadership Academy award. ${ }^{14}$

When considering schemes, review the eligibility criteria carefully, and decide whether an in- or out-of-programme experience is right for you. Most of the RCP's chief registrars remain in programme - which enables the time to count towards training..$^{11}$ Conversely, having a year out of programme can provide the valuable opportunity to test out leadership skills in a new environment, forge new connections with employees working across the public sector - and, in some cases, can open the door to a different career path in policy or the civil service. ${ }^{12}$ If you are currently on a training scheme, remember to apply for prospective approval to go out of programme. Discuss this with your educational supervisor and training programme director well in advance, and ensure you complete the necessary forms for Annual Review of Competency Progression purposes. Consider too what you hope to get out of a scheme, and whether this is the right stage in your career to take time away from clinical practice.

All of us have thoroughly enjoyed our year as a clinical fellow and regard the opportunity as a huge privilege. We hope that the experiential learning and new friendships formed will last a lifetime of clinical practice and would encourage any interested junior doctors to consider applying for a fellowship scheme.

\section{Acknowledgements}

The authors would like to acknowledge the support of the Faculty of Medical Leadership and Management, the RCP, HEE and the Darzi scheme, as well as their respective host organisations for their support and encouragement. 


\section{References}

1 Wheatley MJ. Leadership and the new science, 2nd edn. Oakland: Berrett-Koehler, 1999.

2 Malby R, Anderson-Wallace M. Networks in healthcare: Managing complex relationships, 1st edn. Bingley: Emerald, 2016.

3 West M, West T. Leadership in Healthcare: A Review of the Evidence. HealthManagement 2015;15. https://healthmanagement.org/c/ healthmanagement/issuearticle/leadership-in-healthcare-a-review-ofthe-evidence [Accessed 11 August 2019].

4 Lees P. Clinical leadership - are clinicians up for it? Clin Med 2016;16:5-6.

5 Spurgeon P, Barwell F, Mazelan P. Developing a medical engagement scale (MES). International Journal of Clinical Leadership 2008;16:213-23.

6 Shipton $\mathrm{H}$, Armstrong C, West M, Dawson J. The impact of leadership and quality climate on hospital performance. Int J Qual Health Care 2008:20:439-45.

7 Grint K. Wicked problems and clumsy solutions: the role of leadership. In: Brooks S, Grint K (eds), The new public leadership challenge, 1st edn. London. Springer, 2010:169-86.

8 Edmonstone J, Malby R. Effective medical leadership for a complex NHS. Br J Hosp Med (Lond) 2014;74:461-3.
9 The King's Fund. The future of leadership and management in the NHS: No more heroes. Report from The King's Fund commission on leadership and management in the NHS. London: The King's Fund, 2011.

10 Swanwick T, McKimm J. Faculty development for leadership and management. In: Steinert Y (ed), Faculty Development for the Health Professions. New York: Springer, 2014.

11 Exworthy M, Snelling I. Evaluation of the RCP's chief registrar programme: final report. London: Royal College of Physicians, 2017.

12 McKimm J, Hickford D, Lees P et al. Evaluating the impact of a national clinical leadership fellow scheme. BMJ Leader 2019;3:37-42.

13 Stoll L, Swanwick T, Foster-Turner ] et al. Leadership development for junior doctors: What can we learn from 'Darzi' fellowships in clinical leadership? International Journal of Leadership in Public Services 2011;7:273-86

14 NHS Leadership Academy. Programmes. NHS Leadership Academy. www.leadershipacademy.nhs.uk/programmes [Accessed 14 June 2019].

Address for correspondence: Dr Helen Grote, Department of Neurology, Charing Cross Hospital, Imperial College Healthcare NHS Trust, Fulham Palace Road, London W6 8RF, UK.

Email: helen.grote@nhs.net

\section{Assessing trainees in the workplace}

\section{An e-learning module for secondary care doctors}

Three hours of CPD-approved interactive learning covering:

$>$ feedback

$>$ supervised learning events (SLEs)

$>$ workplace-based assessments (WPBAs)

$>$ the role of the Annual Review of Competence Progression (ARCP).

For more information please visit: www.rcplondon.ac.uk/elearning

\section{Royal College} of Physicians

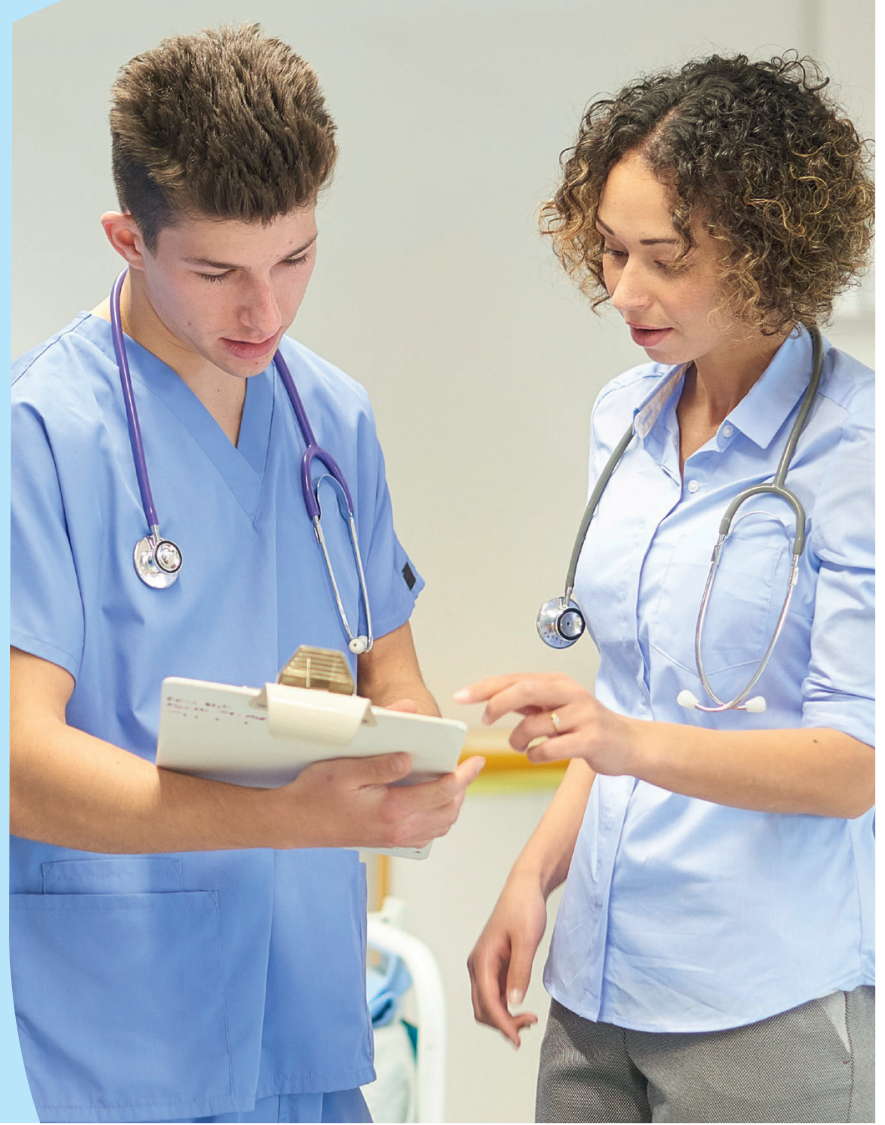

